means of enhancing their product pipeline but as a foundation for a new approach to drug development.

We believe that Japanese deals will require an extraordinary amount of time and effort, but that they can be very beneficial if approached in the right way. For U.S. companies assessing their chances in the partnering arena, managements must understand that a successful deal will take at least one year, if not more, to negotiate; that cultural differences, with good counsel, can be navigated; and that interested parties generally negotiate in good faith.

According to Mark Simon, our senior biotech analyst, perhaps the single most persuasive reason for a U.S. biotech to do a Japanese deal is the importance of monitizing an asset in a market that would otherwise be inaccessible, the result of which will be a loyal partner with a long-term outlook and with significant pools of both capital and expertise. Furthermore, given the current state of the U.S. financial market, such deals are a prudent alternative to raising capital.

GEORGE KIDO JAMES DEVORAK

\title{
COMMENTARY ON PRICING
}

\section{Do low-price guarantees maximize profits?}

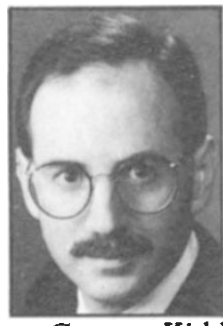

George Kidd

is president of

management

consultants Kidd

\& Company

(Shorewood, WI).

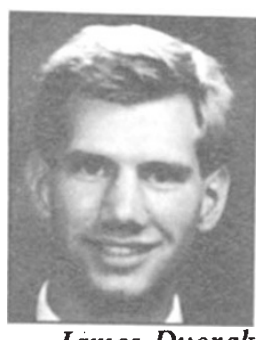

James Dvorak is an associate of Kidd \& Company.
Who in agbiotech is thinking price wars? Everybody's consumed with price premiums for now. For instance, Calgene's (Davis, CA) Flavr Savr tomatoes and DNA Plant Technology's (Oakland, CA) Vinesweet tomatoes are selling at a healthy $\$ 2$ per pound at peak season. Price rollbacks are nowhere in sight.

Though curious consumers are ignoring prices for now, even these first products of agbiotech might give way to pricing pressure sooner than expected. Pioneer Hi-Bred (Des Moines, IA) has announced its entry into the fresh tomato-seed market. Monsanto (St. Louis, MO) has entered, too. Savvy tomato originators like Asgrow (Kalamazoo. MI), who for years has fielded the top Florida tomato variety, and Peto Seed (Saticoy, CA) are not easily dislodged. A dozen other tomato growers and independent plant geneticists are breeding new versions of fresh-market tomatoes. Things are starting to look crowded.

Consumers couldn't be happier. Congestion in a marketplace intensifies competition. Companies in a clutch for market share may resort to the familiar mass merchants' twist, "We match any price" or "The lowest price-guaranteed." Consumers get the best product for the guaranteed low price. What could be more straightforward?

Proponents of game theory-the science of strategic thinking, which was the subject of this year's Nobel Prize in economics-conclude the opposite. Low-price guarantees are not an act of desperation. In fact, they may actually maximize competitors' profits. Game theory- pioneered in the 1940 s by mathematician John von Neumann and economist Oskar Morgensternis an odd combination of math and sociology. It has helped explain the resolution of the massive Kodak-Polaroid lawsuit over instant film, as well as the pitching sequence during U.S. baseball's 1986 National League playoffs.

That low-price guarantees somehow maximize profits - an apparent contradiction -is explained by game theorists Ehud Kalai and Mark Satterthwaite of the J.L. Kellogg Graduate School of Management at Northwestern University (Evanston, IL). Imagine two companies with rational managers. These competitors offer an identical product and have similar costs. When these two businesses charge the same price, they share the market and earn equal profits. As these competitors increase their price, at first, profits grow. Higher revenues result from more sales dollars, while production efficiencies contribute lower costs. However, as the price gets steeper, profits tumble because consumers stop buying, as they believe that the products are too expensive. Along this continuum, the price that consumers will pay and that yields the highest profits is the monopoly price. If collusion were legal, both competitors would obviously choose the monopoly price, because it permits the most profits.

Without collusion, these two competitors follow human nature and end up in a price war. Since these companies can't agree on charging the monopoly price, each has the incentive to undercut its opponent's price by a small, yet noticeable, amount. Prices and profits spiral downward, as each competitor grabs for market share. So far, the basics of Business 101 describe the behavior of these two companies beautifully.

Now enter low-price guarantees. Northwestern's Kalai and Satterthwaite contend that the monopoly price is the only sensible and stable arrangement between two competitors offering low-price guarantees. Pricing above the monopoly level is not intelligent, because either company could reduce its price to the monopoly one and maximize its profits. On the other hand, selling product below the monopoly price isn't shrewd either. With both selling below the monopoly figure, one company may conclude that it has nothing to lose by raising its price to the monopoly level. If its opponent sticks with the lower price, the low-price guarantee kicks in, and both competitors are stuck with lower profits-an undesirable and unlikely choice. Instead, if one company moves from the low price to the monopoly price, the other is likely to follow suit, so both can enjoy the monopoly price's peak profits.

In the real world, however, things might not be so simple. Companies have different cost structures, serve different geographic markets, supply different products, and knock heads with different competitors-all of which temper this elegant explanation of low-price guarantees maximizing profits. Yet are the agbiotech companies improving tomatoes really all that different? Watch out, because strong similarities among these competitors might pave the way for future low-price guarantees./II 